\title{
Evaluation of Biochemical Basis of Resistance in Ber against Powdery Mildew
}

\author{
Meera Choudhary*, R.P. Ghasolia, Tejpal Bajaya and Manisha Shivran \\ Department of Plant Pathology, SKN College of Agriculture (SKNAU), Jobner-303 329, \\ Jaipur, India \\ *Corresponding author
}

\section{A B S T R A C T}

\begin{tabular}{|c|}
\hline Keywords \\
\hline $\begin{array}{l}\text { Ber, Ziziphus } \\
\text { mauritiana, } \\
\text { Powdery mildew, } \\
\text { Total soluble solids, } \\
\text { Total phenol, } \\
\text { Ascorbic acid }\end{array}$ \\
\hline Article Info \\
\hline $\begin{array}{l}\text { Accepted: } \\
\text { 05 April } 2020 \\
\text { Available Online: } \\
10 \text { May } 2020\end{array}$ \\
\hline
\end{tabular}

\section{Introduction}

Indian jujube or ber (Ziziphus mauritiana Lamk.) is one of the most common fruit, indigenous to an area joined from India to China. The genus Ziziphus has been derived from 'Zizaif' which is the Arabic name of the fruit (Bailey, 1947). The ber belongs to the family Rhamnaceae which has about 50 genera and more than 600 species (Pareek, 1983). In India, ber is being cultivated on an area of about 4,845 hectares with production of 66,296 metric tonnes and productivity of 13.68 metric tonnes (Anonymous, 2014). Ber is hardy crop which grown in arid conditions of Rajasthan, characterized by sandy soils, scanty rainfall $(400-600 \mathrm{~mm})$, thermal oscillations (5-35 $\left.{ }^{0} \mathrm{C}\right)$ and low relative humidity. Powdery mildew incited by Oidium erysiphoides f. sp. ziziphi, Yan and Wang is the most important disease that causes maximum reduction in yield and quality of ber (Ziziphus mauritiana Lamk.). In India, the intensity of powdery mildew disease has been recorded from 17 to 71 per cent at fruiting stage of ber (Oidium sp.) in Bijapur (Jamadar et al., 2009). 


\section{Materials and Methods}

\section{Estimation of ascorbic acid}

Ascorbic acid (vitamin C) content in fresh ber fruits was determined by diluting the known weight of pulp with 3 per cent metaphosphoric acid to appropriate volume and titrating it with 2, 6-dichlorophenol indophenols dye solution after standardization till the faint pink colour was obtained. The average values were expressed as $\mathrm{mg}$ ascorbic acid per $100 \mathrm{~g}$ fresh fruit pulp (A.O. A. C. 1990).

\section{Estimation of TSS}

Fresh fruits and leaves from selected ber varieties were taken and macerated separately for juice extraction and total soluble solids (TSS) of the extract was determined by using a hand refractometer of 0-32 per cent range. In this case, one drop of fruit pulp and leaf juice was put separately on the prism of the refractometer and per cent TSS was recorded directly. The values were corrected at $20{ }^{\circ} \mathrm{C}$ and expressed as per cent total soluble solids of the fruits and leaves juice (A.O. A. C. 1990).

\section{Estimation of total phenol}

The content of total phenol present in the fruits and leaves was estimated as per method suggested by Malik and Singh (1980). According to this, weighed $0.5 \mathrm{~g}$ of fresh leaves without midrib and fresh fruit pulp (0.5 g) and ground these separately with mortar and pestle in $10 \mathrm{ml}$ of 80 per cent ethanol. Thus, homogenate or extract obtained was centrifuged at $8000 \mathrm{rpm}$ for 10 minutes. Extraction was repeated four times with $5 \mathrm{ml}$ of 80 per cent ethanol each time and supernatants were collected into same beaker. Volume of the extract was made to $50 \mathrm{ml}$ with 80 per cent ethanol.
One $\mathrm{ml}$ of supernatant was taken and evaporated to dryness in water bath. One $\mathrm{ml}$ of millipore water in each test tube and $0.5 \mathrm{ml}$ of Folin \& Ciocalteu reagent (1:1 with water) was added and kept for three min. After this, $2 \mathrm{ml}$ of 20 per cent $\mathrm{Na}_{2} \mathrm{CO}_{3}$ was added and mixed thoroughly. The tubes were placed in boiling water for exactly one minute and cooled in ice water. The absorbance was read at $650 \mathrm{~nm}$ against a reagent blank.

\section{Results and Discussion}

\section{TSS}

Changes in the content of total soluble solids, ascorbic acid and total phenols were estimated in fruits and leaves (except ascorbic acid) of healthy and infected (Oidium erysiphoides f. sp. ziziphi) fruits and leaves of moderately susceptible (Kaithali and Mehroon) and susceptible (Gola and Thornless) varieties of ber (Ziziphus mauritiana) at peanut and immature stages of fruits (Table 1) and tender and maturing stages of leaves (Table 2) of ber.

Initially, the level of TSS was lower in healthy fruits of moderately susceptible varieties i.e. Kaithali and Mehroon (7.03 \& $9.03 \%$, respectively) of ber at peanut stage while at immature stage it was 15.53 and 15.40 per cent, respectively whereas the level of TSS was higher in healthy fruits of susceptible varieties i.e. Gola and Thornless of ber at peanut and immature stages (11.86$15.93 \%$ and $10.90-18.16 \%$, respectively).

Our results are in the agreement with findings of Pradeep and Jambhale (2001). They observed increased level of TSS and ascorbic acid in healthy fruits of resistant and susceptible genotype of ber at unripe and ripe stages. 
Table.1 Biochemical changes in healthy and infected (Oidium erysiphoides f. sp. ziziphi) fruits of different varieties of ber at peanut and immature stages

\begin{tabular}{|c|c|c|c|c|c|c|c|c|c|}
\hline Cultivars & $\begin{array}{l}\text { Disease } \\
\text { Reaction }\end{array}$ & Stages & Category & $\begin{array}{l}\text { TSS } \\
(\%) *\end{array}$ & $\begin{array}{l}\text { \% decrease } \\
\text { in TSS over } \\
\text { healthy }\end{array}$ & $\begin{array}{l}\text { Ascrobic } \\
\text { acid } \\
(\mathrm{mg} / \mathbf{1 0 0 g}) *\end{array}$ & $\begin{array}{l}\% \text { decrease in } \\
\text { ascorbic acid } \\
\text { over healthy }\end{array}$ & $\begin{array}{l}\text { Total } \\
\text { Phenol } \\
(\mathrm{mg} / \mathrm{g}) *\end{array}$ & $\begin{array}{lr}\text { \% } & \text { Increase } \\
\text { in } & \text { phenol } \\
\text { over healthy }\end{array}$ \\
\hline \multirow[t]{4}{*}{ Kaithali } & MS & Peanut & $\mathrm{H}$ & 7.03 & & 45.73 & & 0.086 & - \\
\hline & & & $\mathrm{D}$ & 4.30 & 38.83 & 39.16 & 14.34 & 0.126 & 46.51 \\
\hline & & Immature & $\mathrm{H}$ & 15.53 & & 58.86 & & 0.074 & - \\
\hline & & & $\mathrm{D}$ & 13.43 & 13.52 & 54.31 & 7.73 & 0.101 & 36.49 \\
\hline \multirow[t]{4}{*}{ Mehroon } & MS & Peanut & $\mathrm{H}$ & 9.03 & & 40.97 & & 0.091 & - \\
\hline & & & $\mathrm{D}$ & 5.30 & 41.30 & 32.17 & 21.47 & 0.138 & 51.65 \\
\hline & & Immature & $\mathrm{H}$ & 15.40 & & 66.14 & & 0.082 & - \\
\hline & & & $\mathrm{D}$ & 13.43 & 12.79 & 61.47 & 7.06 & 0.118 & 43.90 \\
\hline \multirow[t]{4}{*}{ Gola } & $\mathrm{S}$ & Peanut & $\mathrm{H}$ & 11.86 & & 41.00 & & 0.062 & - \\
\hline & & & $\mathrm{D}$ & 8.26 & 30.35 & 32.16 & 21.56 & 0.081 & 30.64 \\
\hline & & Immature & $\mathrm{H}$ & 15.93 & & 56.14 & & 0.047 & - \\
\hline & & & $\mathrm{D}$ & 15.03 & 5.65 & 50.37 & 10.28 & 0.058 & 23.40 \\
\hline \multirow[t]{6}{*}{ Thornless } & $S$ & Peanut & $\mathrm{H}$ & 10.90 & & 40.07 & & 0.059 & - \\
\hline & & & $\mathrm{D}$ & 7.87 & 27.79 & 27.90 & 30.37 & 0.076 & 28.81 \\
\hline & & Immature & $\mathrm{H}$ & 18.16 & & 70.47 & & 0.046 & - \\
\hline & & & $\mathrm{D}$ & 15.50 & 14.65 & 61.37 & 12.91 & 0.054 & 17.39 \\
\hline & & \multicolumn{2}{|c|}{ SEm \pm} & 0.79 & & 3.18 & & 0.005 & - \\
\hline & & \multicolumn{2}{|c|}{$\mathrm{CD}(\overline{\mathrm{p}}=\mathbf{0 . 0 5})$} & 2.44 & & 9.80 & & 0.015 & - \\
\hline
\end{tabular}

*Average of three replications, TSS $=$ Total soluble solids, $\mathrm{H}=$ Healthy, $\mathrm{D}=$ Diseased

Peanut stage $=45-50$ days after fruit setting, Immature stage $=65-70$ days after fruit setting, MS= Moderately susceptible, $S=$ Susceptible 
Table.2 Biochemical changes in healthy and infected (Oidium erysiphoides f. sp. ziziphi) leaves of different varieties of ber at tender and maturing stages

\begin{tabular}{|c|c|c|c|c|c|c|c|}
\hline Cultivars & $\begin{array}{l}\text { Disease } \\
\text { reaction }\end{array}$ & Stages & Category & $\begin{array}{l}\text { TSS } \\
(\%)^{*}\end{array}$ & $\begin{array}{c}\text { \% decrease in } \\
\text { TSS over } \\
\text { healthy }\end{array}$ & $\begin{array}{c}\text { Total } \\
\text { Phenol } \\
(\mathrm{mg} / \mathrm{g})^{*}\end{array}$ & $\begin{array}{c}\text { \% Increase in } \\
\text { phenol over } \\
\text { healthy }\end{array}$ \\
\hline \multirow[t]{4}{*}{ Kaithali } & MS & TL & $\mathrm{H}$ & 3.27 & & 0.882 & \\
\hline & & & $\mathrm{D}$ & 2.57 & 21.41 & 0.981 & 11.22 \\
\hline & & ML & $\mathrm{H}$ & 4.74 & & 0.767 & \\
\hline & & & $\mathrm{D}$ & 3.83 & 19.19 & 0.828 & 7.95 \\
\hline \multirow[t]{4}{*}{ Mehroon } & MS & TL & $\mathrm{H}$ & 4.23 & & 0.662 & \\
\hline & & & $\mathrm{D}$ & 2.76 & 34.75 & 0.748 & 12.99 \\
\hline & & ML & $\mathrm{H}$ & 5.47 & & 0.430 & \\
\hline & & & $\mathrm{D}$ & 4.31 & 21.21 & 0.469 & 9.07 \\
\hline \multirow[t]{4}{*}{ Gola } & $\mathrm{S}$ & $\mathrm{TL}$ & $\mathrm{H}$ & 3.82 & & 0.705 & \\
\hline & & & $\mathrm{D}$ & 2.23 & 41.62 & 0.765 & 8.5 \\
\hline & & ML & $\mathrm{H}$ & 5.63 & & 0.413 & \\
\hline & & & $\mathrm{D}$ & 4.46 & 20.78 & 0.433 & 4.84 \\
\hline \multirow[t]{6}{*}{ Thornless } & $\mathrm{S}$ & $\mathrm{TL}$ & $\mathrm{H}$ & 3.97 & & 0.691 & \\
\hline & & & $\mathrm{D}$ & 2.31 & 41.81 & 0.744 & 7.67 \\
\hline & & ML & $\mathrm{H}$ & 5.63 & & 0.546 & \\
\hline & & & $\mathrm{D}$ & 4.43 & 21.31 & 0.574 & 5.13 \\
\hline & & \multicolumn{2}{|c|}{ SEm \pm} & 0.26 & - & 0.042 & - \\
\hline & & \multicolumn{2}{|c|}{$C D(p=\overline{0.05})$} & 0.80 & - & 0.121 & - \\
\hline
\end{tabular}

*Average of three replications,

TSS= Total soluble solids, $\mathrm{TL}=$ Tender leaves, $\mathrm{ML}=$ Maturing leaves, $\mathrm{MS}=$ Moderately susceptible, $\mathrm{S}=$ Susceptible, $\mathrm{H}=\mathrm{Healthy}, \mathrm{D}=\mathrm{Diseased}$ 


\section{Ascorbic acid}

After infection by Oidium erysiphoides f. sp. ziziphi, the level of ascorbic acid (Table 1) was decreased maximum in susceptible variety Thornless $(30.37 \%)$ followed by Gola $(21.56 \%)$ at peanut stage and 12.91 per cent and 10.28 per cent at immature stage, respectivley while in case of moderately susceptible varieties (Mehroon \& Kaithali), the ascorbic acid level was also reduced at peanut $(21.47 \% \& 14.34 \%)$ and at immature stage $(7.06 \% \& 7.73 \%$, respectively). Due to this increased acidity, large sized fruits might not be infected by the powdery mildew pathogen. These results are supported by the findings of Madan and Thind (1998) and Hanson (2008). They reported that fungus is requiring a slightly acidic medium to proliferate and deteriorate medium. The Vitamin-c content of many fruits such as sour orange, cashew apple, mango, pineapple, orange and guava is higher when they are slightly immature and decline as they hits peak ripeness (Mohammad et al., 2014).

\section{Total phenol}

The total phenol was higher in healthy fruits (Table 1) of moderately susceptible varieties i.e. Kaithali and Mehroon (0.086 and 0.091 $\mathrm{mg} / \mathrm{g}$, respectively) of ber at peanut stage while at immature stage it was $0.074 \mathrm{mg} / \mathrm{g}$ and $0.082 \mathrm{mg} / \mathrm{g}$, respectively whereas the level of total phenol was lower in healthy fruits of susceptible varieties i.e. Gola \& Thornless of ber at peanut and immature stages (0.062-0.047 mg/g and 0.059-0.046 $\mathrm{mg} / \mathrm{g}$, respectively). Total phenol was also estimated at tender and maturing stages of both healthy and infected leaves of ber (Table 2). Similar trend in level of total phenol was observed in healthy and infected leaves of ber at tender and maturing stage of leaves. In the present investigation, the concentration of total phenol was slightly higher at peanut stage where as immature stage it was decreased. However, after infection the phenol content was significantly increased in leaves and fruits of ber as compared to healthy ones. It is also observed that per cent increase in phenol content was maximum in moderately susceptible varieties (Kaithali and Mehroon) than susceptible ones (Gola and Thornless). In these biochemicals, the concentration of phenol content was recorded at increased level among phenolic substances in different host-pathogen system after infection (Patil and Dimond, 1967, Ravise and Trique, 1972). Rapid increase in phenolic synthesis due to infection has been correlated with disease resistance in many host-pathogen interactions (Vidhyasekaran, 2004). Powdery mildew colonized (Oidium erysiphoides f. sp. ziziphi) immature and mature fruits and tender, maturing and old leaves of ber accumulated significantly more phenol, which may be attributed to the defense mechanisms (Nallathambi et al., 2009).

\section{References}

A.O. A. C. (1990). Official Methods of Analysis, Washington D. C. $9^{\text {th }}$ Edn. Pp. 15-16.

Anonymous. (2014). Indian Horticulture Database-2014, National Horticulture Board, Gurgaon.

Baily, L. H. (1947). The Standard a of Horticulture. MacMillan and Co., New Yark. pp. 3547-8.

Hanson, J. R. (2008). The Chemistry of Fungi. Royal Society of Chemistry, Univ. of Sussex, Brighton, UK, pp 221.

Jamadar, M. M., Balikai, R. A. and Sataraddi, A. R. (2009). Status of diseases on ber (Ziziphus mauritiana Lamk.) in India and their management options. Acta Hort. 840: 383- 390.

Madan, M. and Thind, K. S. (1998). Physiology of fungi. APH Publishing Corporation, 5, Ansari Road, Darya 
Gang, New Delhi, pp. 240.

Malik, C. P. and Singh M. B. (1980). Plant Enzymology and Histoenzymology. Kalyani Pub., New Delhi, p. 286.

Mohammad, I., Ashiru, S., Ibrahim, I., Kanoma, A. I., Sani, I., and Garba, S. (2014). Effect of ripening stage on vitamin $\mathrm{C}$ content in selected fruits. International J. Agri., Forestry Fisheries. 2(3): 60-65.

Nallathambi, P, Umamaheswari, C, More, T. A. (2009). Phenolics and phenol oxidising enzymes activity as index for screening ber (Ziziphus mauritiana) germplasm against powdery mildew (Oidium erysiphoides). Indian J. Agri. Sci. 79 (10): 838-840.

Pareek, O. P. (1983). The Jujube. Indian Council of Agricultural Research, New Delhi pp. 7.
Patil, S. S. and Dimond, A. E. (1967). Inhibition of Verticillium polygalacturonase by oxidation products of polyphenol. Phytopathol. 57: 492.496.

Pradeep, T. and Jambhale, N. D. (2001). Biochemical factors in powdery mildew resistance of ber (Ziziphus mauritiana Lamk.) genotypes varying in ploidy levels. Indian J. Genetics Plant Breed. 61(4): 379-380.

Ravise, A. and Trique, B. (1972). Determination des enzymes pectinolytique de deux souches de Phytophthora. Agron. Tropicale. 27: 751-762.

Vidhyasekarn, P. (2004). Concise Encyclopaedia of Plant Pathology. Viva Books Pvt. Ltd., Ltd., New Delhi, pp. 538.

\section{How to cite this article:}

Meera Choudhary, R.P. Ghasolia, Tejpal Bajaya and Manisha Shivran. 2020. Evaluation of Biochemical Basis of Resistance in Ber against Powdery Mildew. Int.J.Curr.Microbiol.App.Sci. 9(05): 539-544. doi: https://doi.org/10.20546/ijcmas.2020.905.061 